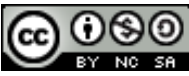

https://doi.org/10.31743/abmk.9922

\title{
PÓŹNOŚREDNIOWIECZNE SUPEREKSLIBRISY MIKOLAJA HESKENA Z KOŚCIANA. CYMELIA ZE ZBIORÓW ARCHIWUM ARCHIDIECEZJALNEGO W POZNANIU ${ }^{1}$
}

\begin{abstract}
Streszczenie
Pozostałości po późnośredniowiecznym księgozbiorze kanonika poznańskiego Mikołaja Heskena z Kościana (zm. 1485 r.) znajdują się obecnie w zbiorach Archiwum Archidiecezjalnego w Poznaniu. Podczas swoich badań ks. Kamil Kantak opisał jego zbiór, zwracając uwagę na „pieczątki” znajdujące się na oprawach ksiąg. Autor artykułu po przeprowadzeniu bliższej analizy stwierdził, że wspomniane ,pieczątki” są superekslibrisami Mikołaja Heskena wyciśniętymi za pomocą tłoków pieczętnych. Dalsze badania wykazały, że jest to cenny i wartościowy materiał do dziejów książkowych znaków własnościowych w Polsce. Świadczy o tym m.in. chronologia superekslibrisów, która czyni je najstarszymi w Wielkopolsce.
\end{abstract}

Słowa kluczowe: Mikołaj Hesken z Kościana; Archiwum Archidiecezjalne w Poznaniu; superekslibris; pieczęć; herb Drogosław; św. Katarzyna;

tegumentologia; introligatorstwo; sfragistyka

* Radosław Franczak - mgr historii, doktorant w Instytucie Historii, Uniwersytet Adama Mickiewicza w Poznaniu

e-mail: rad.fran7@gmail.com

https://orcid.org/0000-0002-1603-629X

${ }^{1} \mathrm{~W}$ tym miejscu pragnę złożyć podziękowania ks. Romanowi Dworackiemu dyrektorowi Archiwum Archidiecezjalnego w Poznaniu za umożliwienie mi skorzystania ze zbioru inkunabułów oraz pracownikom niniejszej placówki za pomoc i miłą obsługę. Osobne podziękowania należą się: dr. hab. prof. UAM Piotrowi Pokorze, za konsultacje merytoryczne w dziedzinie sfragistyki oraz literatury, dr. hab. prof. UMK Arkadiuszowi Wagnerowi za udostępnienie mi swojej pracy habilitacyjnej jeszcze przed jej wydaniem oraz za konsultacje merytoryczne w dziedzinie tegumentologii, a także mgr. Jakubowi Łukaszewskiemu za wszelką pomoc. 
Postać Mikołaja Heskena z Kościana (†1485 r.) jest dość dobrze znana w literaturze $^{2}$. Był osobą wykształconą z tytułem doktora dekretów. Poświęcił się karierze duchownej, w trakcie której sprawował liczne funkcje kościelne. Do najważniejszych zaliczyć można urząd oficjała i wikariusza generalnego poznańskiego (1449-1450) oraz godność kanonika katedralnego poznańskiego (od 1454 r.). Prawdopodobnie posiadał zasobną bibliotekę, z której co najmniej kilka woluminów podarował klasztorowi cystersów w Paradyżu. Do dziś po księgozbiorze kanonika pozostała niewielka jego część, w postaci sześciu inkunabułów ${ }^{3}$ i jednego rękopisu, przechowywana w Archiwum Archidiecezjalnym w Poznaniu ${ }^{4}$. Niniejszy zbiór zwrócił uwagę kilku badaczy, lecz do tej pory nie został całościowo i dokładnie przebadany. Przede wszystkim skupiano się na analizie zawartości treściowej, pomijając analizę oprawoznawczą ${ }^{5}$ Jedynym spośród badaczy, który zainteresował się tą kwestią i jako jeden z pierwszych dokonał dokładniejszego opisu księgozbioru kanonika, był ks. Kamil Kantak. W swoim dwuczęściowym dziele Spis Książek z XV wieku z Ksiąznicy Seminarjum Duchownego w Poznaniu stwierdził na temat Mikołaja Heskena:

(...) Własnoręcznie bowiem choć nie bardzo zgrabnie malował inicjały oraz na końcu herb Drogosław i sam pisał obszerne skorowidze, co do których używania podał na końcu wspomnianej już Glossy dokładne objaśnienie. (...) Przy trzech księgach porwał się nawet na własnoręczną oprawę. (...) Oprawy Mikołaja składają się z białego pergaminu. Ten pergamin przeciągał wielkim krzyżem greckim o podwójnych liniach czerwonym inkaustem zrobionych, a powstałe tym sposobem cztery trójkąty na wierzchniej i spodniej okładce wypełnił odciskami pieczątki. Nadto na okładce również czerwonym inkau-

${ }^{2}$ P. Dembiński, Poznańska kapituła katedralna schyłku wieków średnich. Studium prozopograficzne 1428-1500, Poznań 2012, s. 544-546; J. Krzyżaniakowa, Mikołaj z Kościana, w: Polski Słownik Biograficzny, t. 21, red. E. Roztworowski, Wrocław 1976, s. 116-117; H. Tadeusiewicz, Mikołaj z Kościana, w: Słownik pracowników książki polskiej. Suplement, red. I. Reichel, Warszawa 1986, s. 143; J. Wiesiołowski, Hesken Mikołaj z Kościana, w: Wielkopolski słownik biograficzny, red. A. Gąsiorowski, T. Topolski, Warszawa 1981, s. 252-253.

${ }^{3}$ Archiwum Archidiecezjalne w Poznaniu (dalej: AAP), sygn. Inc. 149, Inc. 187, Inc. 278, Inc. 280, Inc. 313, Inc. 314; por. K. Kantak, Spis ksiażek z XV wieku Ksiązinicy Seminarjum Duchownego w Poznaniu. Część pierwsza, „Rocznik Towarzystwa Przyjaciół Nauk Poznańskiego”, 45 (1918) s. 32-33 nr 85, s. 35 nr 97, s. 46 nr 144; tenże, Spis ksiażek z XV wieku Książicy Seminarjum Duchownego w Poznaniu. Część pierwsza (dokończenie), „Rocznik Towarzystwa Przyjaciół Nauk Poznańskiego", 46 (1919) s. 249-250 nr 184, s. 264-266 nr 233, s. $271 \mathrm{nr} 251$.

${ }^{4}$ AAP, sygn. MS 17. W katalogu A. Lisieckiego wymieniony jest jeszcze jeden rękopis MS 44 z proweniencją Mikołaja Heskena, który obecnie jest zaginiony. Por. A. Lisiecki, Katalog rękopisów biblioteki seminaryjnej w Poznaniu aż do wieku XV włącznie: dokończenie, Poznań 1905, s. 121122.

${ }^{5} \mathrm{Na}$ temat księgozbioru Mikołaja z Kościana pisali: G. Piechota, Mikołaj z Kościana i jego ksieggozbiór, „Folia Bibliologica”, 48/49 (2006/2007) s. 25-39; J. Wiesiołowski, Społeczeństwo a książka w późnośredniowiecznym mieście polskim Poznań i jego osiedla przedmiejskie w XV i na początku XVI wieku, „Studia Źródłoznawcze”, 23 (1978) s. 70. 
stem pokładł jeszcze odpowiednie tytuły. Pergamin wszakże na okładkę był za miękki. (...) Nasz Mikołaj zaś w tym celu brał rozmaite papiery (...) i kładł pod pergamin $(\ldots)^{6}$.

Dla niniejszego artykułu istotą są przede wszystkim odnotowane przez Kantaka „pieczątki”, które przy opisie katalogowym nazywał również ,pieczęciami z Matką Boską"

Przeprowadzona kwerenda w zbiorach inkunabułów Archiwum Archidiecezjalnego w Poznaniu udowodniła, że wspomnianym wyżej mianem Kantak określił dwa rodzaje superekslibrisów herbowych właściwych wyciśniętych za pomocą tłoków pieczętnych na dwóch woluminach ${ }^{8}$. Pierwszy znak własnościowy (okrągły) posiada średnicę $27 \mathrm{~mm}$ (dalej: typ 1). W polu tej pieczęci na pochylonej tarczy gotyckiej znajduje się godło herbu Drogosław. Za tarczą św. Katarzyna Aleksandryjska wyobrażona w ujęciu do pasa z lewą ręką opartą na tarczy herbowej i kołem w prawej. Głowa świętej jest ozdobiona zawojem lub chustą. W otoku na filakterii znajduje się inskrypcja, w dolnej części pieczęci rozdzielona tarczą herbową: S(igillum) * NICO / LAI D(e) COSTEN (il. 1-2).
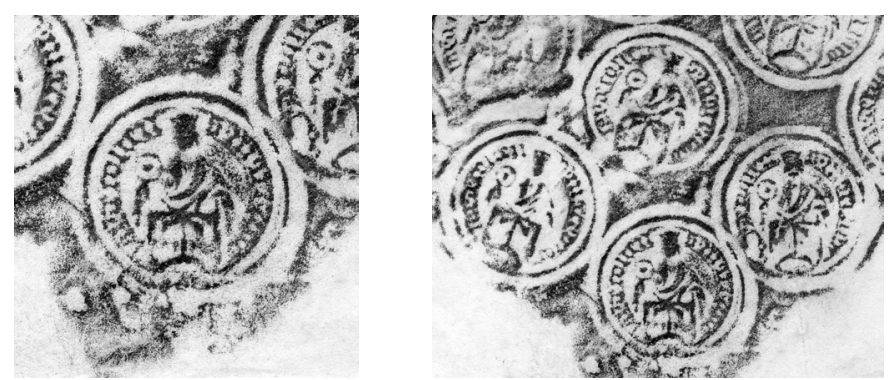

Il. 1-2 Superekslibris herbowy właściwy Mikołaja Heskena (typ 1), 1475 r. Archiwum Archidiecezjalne w Poznaniu, sygn. Inc. 313. Fot. R. Franczak.

Pojawiająca się na superekslibrisie św. Katarzyna jest wzmiankowana także we wpisach proweniencyjnych Heskena ${ }^{9}$ i można uznać ją za jego patronkę. Prawdopodobnie wpływ na wybór świętej przez doktora dekretów mogła mieć przypisywana jej opieka nad uczonymi. Drugi superekslibris (dalej: typ 2) wyciśnięto za pomocą sygnetu pieczętnego ośmiobocznego o wymiarach przekątnych

${ }^{6}$ Kantak, Spis książek z XV wieku, s. 10.

${ }^{7}$ Tenże, Spis książek z XV wieku (dokończenie), s. 264-266 nr 233, s. $271 \mathrm{nr} 251$.

${ }^{8}$ AAP, sygn. Inc. 313: Rabanus Maurus, De sermonum proprietate, sive Opus de universe, [Strasbourg, R - typographus=Adolphus Rusch, non post 1474], $2^{\circ}$; AAP, sygn. Inc. 314: Petrus Lombartus, Glossa in Epistolas Pauli, [Esslingen, Conradus Fyner, ante 12 XII 1473], $2^{\circ}$; zob. Gesamtkatalog der Wiegendrucke (wersja online: https://www.gesamtkatalogderwiegendrucke.de), nr 13557 i M32577 (dostęp: 29.09.2020); Incunabula quae bibliothecis Poloniae asservantur, vol. 1, moderante A. Kawecka-Gryczowa, composuerunt M. Bohonos et E. Szandorowska, Wratislaviae -Varsaviae-Cracoviae 1970, nr 4328 i 4657; Kantak, Spis książek z XV wieku (dokończenie), s. 264$266 \mathrm{nr} 233$, s. $271 \mathrm{nr} 251$.

${ }^{9}$ Zob. przyp. 13-15. 
$13 \times 15 \mathrm{~mm}$. W polu tej pieczęci na tarczy gotyckiej wyobrażone jest godło herbu Drogosław. Wokół niej znajduje się inskrypcja: * S(igillum) * NICOLAI D(e) COSTEN (il. 3-4).
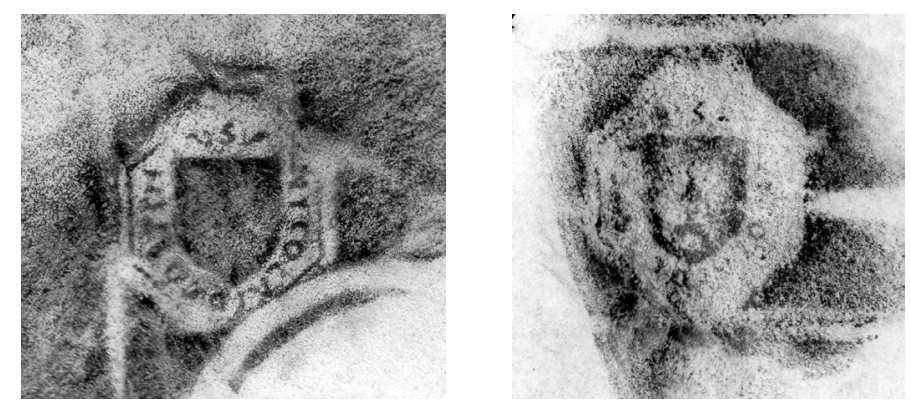

Il. 3-4 Superekslibris herbowy właściwy Mikołaja Heskena (typ 2), 1475 r. Archiwum Archidiecezjalne w Poznaniu, sygn. Inc. 313. Fot. R. Franczak.

Oprawy sporządzono z jasnej skóry i makulatury, którą wyjęto i zastąpiono tekturą $^{10}$. Na dłuższych i krótszych krawędziach znajdują się ślady po zapięciach. $\mathrm{Na}$ okładzinach obu woluminów za pomocą strychulca wyciśnięto ramę, listwę poziomą w centrum oraz listwy w postaci przekątnych. W ten sposób zwierciadło podzielono na dwie części, w których utworzono po trzy trójkątne pola. Miejscami umieszczono odręczne inskrypcje oraz podkreślenia czerwonym i zielonym inkaustem wypełniające linie strychulcowe. Całość dekoracji dopełniają wyciski superekslibrisów, lecz w różnej kompozycji.

Na okładzinie górnej woluminu Inc. 313 jedna część zwierciadła jest gęsto wypełniona wyciskami superekslibrisu typu 1. Inaczej ozdobiono drugą część, której skrajne prawe pole wypełniono w całości wyciskami superekslibrisu typu 2, a skrajne lewe typu 1 . Natomiast $\mathrm{w}$ centralnym polu znajdują się oba rodzaje wycisków. Na wyróżnienie zasługują odręczne inskrypcje ze względu na zawarcie w nich daty: MCCCCLXXV oraz danych autora: Rabenus. Na okładzinie dolnej dominują przede wszystkim wyciski superekslibrisu ze św. Katarzyną (typ 1), które umieszczono na prawie całej powierzchni zwierciadła oraz w narożach ramy i na przecięciu centralnej listwy z przekątnymi. Rzadziej wyciśnięto superekslibris sygnetowy (typ 2), który miejscami wypełnia wewnętrzne narożniki trójkątnych pól.

W odmienny sposób rozmieszczono wyciski znaków własnościowych na oprawie Inc. 314. Na okładzinie górnej wyciśnięto w określonym porządku kilkanaście razy superekslibris typu 1 ze św. Katarzyną. Został on umieszczony w centralnych polach obu części zwierciadła oraz pojedynczo w prawym skrajnym górnej części. Wyciśnięto go także trzykrotnie na poziomej listwie. Natomiast ramę oraz przekątne wypełnia superekslibris wykonany za pomocą sygnetu (typ 2). Na

${ }^{10}$, ,...) Nasz Mikołaj zaś w tym celu brał rozmaite papiery, sklejał z sobą, aż nie nabrał potrzebnej grubości i twardości, i kładł pod pergamin. Między temi papierami znalazł się cały szereg dokumentów. Obecnie papiery te wyjęto i zastąpiono zwyczajnym kartonem (...)", Kantak, Spis ksiązek $z X V$ wieku, s. 10. 
dolnej okładzinie wyciski umieszczono podobnie z niewielką różnicą, mianowicie przekątne pozostawiono bez zdobień. Dodatkowo górną część okładziny uzupełniono o inny superekslibris z godłem Drogosław w prostokątnej ramie o rozmiarach $30 \times 50 \mathrm{~mm}$ wyciśnięty strychulcem (il. 5).

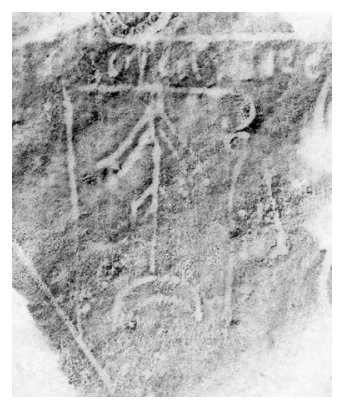

Il. 5 Superekslibris Mikołaja Heskena wyciśnięty za pomocą strychulca, 1475.

Archiwum Archidiecezjalne w Poznaniu, sygn. Inc. 314. Fot. R. Franczak.

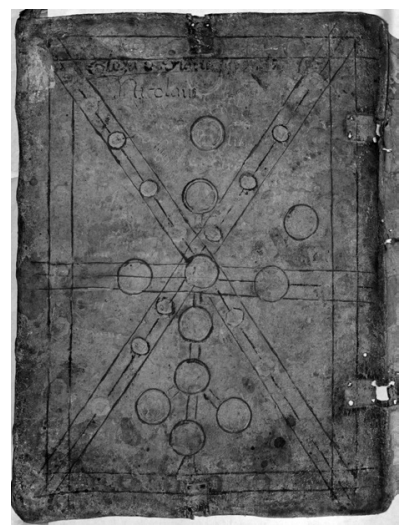

I1. 6. Górna okładzina oprawy. Archiwum Archidiecezjalne w Poznaniu, sygn. Inc. 314.

Fot. Archiwum Archidiecezjalne w Poznaniu

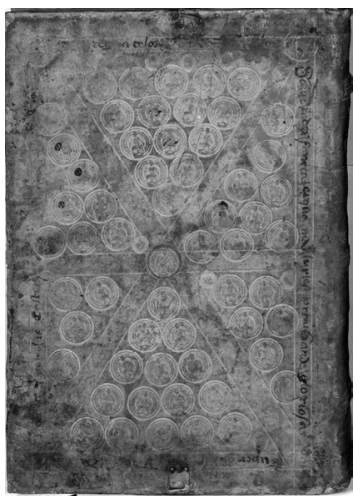

Il. 7. Dolna okładzina oprawy. Archiwum Archidiecezjalne w Poznaniu, sygn. Inc. 313.

Fot. Archiwum Archidiecezjalne w Poznaniu 
Glosy umieszczone na kartach woluminu Inc. 314 pozwalają na określenie dokładnego czasu jego nabycia i oprawienia. Wydany ok. 1473 r. druk został pozyskany przez kanonika przed dniem 12 grudnia 1473 r., w którym, jak zapisał, wykonał iluminacje niniejszego egzemplarza, w tym zapewne malowany herb Drogosław na dwóch kartach ${ }^{11}$. W innej glosie Mikołaj Hesken informuje, że egzemplarz oprawił w $1475 \mathrm{r} .^{12}$, a w kolejnej dodaje, że uczynił to własnoręcznie ${ }^{13}$. Można tylko przypuszczać, że miało to miejsce na terenie diecezji poznańskiej (w Poznaniu?), z którą był najbardziej związany. Następny wpis świadczy już o przekazaniu woluminu klasztorowi cystersów w Paradyżu w dniu 20 września $1475 \mathrm{rr}^{14}$

Zapiski Heskena w przypadku woluminu Inc. 313 również pozwalają rozwiązać podobne kwestie. Wynika z nich, że druk nabył 17 lipca 1475 r. w Poznaniu ${ }^{15}$, a następnie 20 września przekazał wolumin klasztorowi cystersów w Paradyżu ${ }^{16}$. Podobieństwo oprawy z egzemplarzem Inc. 314 wskazuje, że również i w tym przypadku mógł ją wykonać Mikołaj Hesken, niewątpliwie pomiędzy 17 lipca a 20 września 1475 r., przypuszczalnie na terenie diecezji poznańskiej.

${ }^{11}$ MCCCCLXXIII Die lune XII dece(m)bris ill(u)m(in)ati su(n)t hii Qu(a)t(er)ni et completi per $m(a) g(i s t) r(u) m$ Nicolau(m) de Costen decretor(um) doctore $(m)$ Canonicu(m) poznanien(sis) valor libri VIIIflor(enorum) hungari(co)ru(m); zob. Kantak, Spis książek z XV wieku (dokończenie), s. 264 nr 233.

${ }^{12}$ Anno Doi(ni) MCCCCLXXV (com)pletus est hic liber et int(ro)ligat(us) p(er)lect(us) correct(us) et hinc inde glosat(us) cu(m) addic(i)o(n)ib(us) et (con)cordantiis(?) doctor(um) in i(m)aginib(us) p(er) me Nicola(um) de Costen decretor(um) doctorem Can(oni)cu(m) Eccl(es)i(a)e p(o)z(nanie)n(sis) valor libri VIII(?) fl(ore)n(orum) hungari(corum) deo graci(as); zob. Kantak, Spis ksiażek z XV wieku (dokończenie), s. $264 \mathrm{nr} 233$.

${ }^{13}$ (...) Hoc cum compleuissem, in quando potui, introligaui eciam propriis manibus et consummaui (...); zob. Kantak, Spis książek z XV wieku (dokończenie), s. 266.

${ }^{14}$ Hunc libru(m) dedicaui in honorem Gloriosissi(m)e v(ir)gini marie et Egregie V(ir)gini S(an) cte Katherine p(ro) Sacratissimo mo(na)sterio paradise et donaui manualiter ilud in Mo(n)asterio et existens tradidi et $h u(n)$ c titulum $p(r o) p(r i)$ a manu scripsi (...) Nicolaus de Costen decretor(um) doctor etc. p(ro) salute a (n)i(m)e mee Anno domi(ni) quo sup(ra) s(cilicet) MCCCCLXXV die veneris xx mensis Septembris Sit laus deo; zob. Kantak, Spis książek z XV wieku (dokończenie), s. 265266.

${ }^{15}$ Anno Dom(in)i MCCCCLXXV emi hu(n)c libr(um) pozn(aniensis) die jouis XVII mensis Julii Ego Nicolaus Costen decretor(um) doctor Ca(nonic)us pozn(aniensis) Eccl(es)i(a)e ad laud(em) dei et eius intemerate v(ir)gi(ni)s marie et Gloriose v(ir)gi(ni)s B(ea)te Katherine P(re)cor a lector quocienscunq(ue) leger(is) die p(ro) me vnum Ave Maria Deo gracias valor hui(us) libri VIII florenor(um) hungari(corum); Kantak, Spis książek z XV wieku (dokończenie), s. $271 \mathrm{nr} 251$.

${ }^{16} \mathrm{Hu}(\mathrm{n}) \mathrm{c}$ libr(um) dedicaui Ego Nicolaus de Costen decretor(um) doctor Can(o)n(i)c(us) pozn(aniensis) in honorem Gloriosissi(m)e v(ir)gi(ni)s marie Genitri(cis) Saluator(is) dom(in)i nostri (Jesu) (Christi) Et Egregie v(ir)gi(ni)s S(an)cte Katharine p(ro) mo(na)sterio S(an)ctissi(m)o P(ar) adisi ordi(ni)s Cistercien(sis) dioe(cesis) pozn(aniensis) et donaui manualiter in eod(em) mo(na) sterio existens et t(ra)didi Reuerendo patri d(omi)no Joha(n)ni abbati eiusd(em) mo(na)sterii et p(ro)p(ri)a manu hu(n)c donac(i)o(nis) titulu(m) scripsi in fidem et testimoniu(m) p(re)missior(um) p(ro) a (n)i(m)e mee salute Anno D(omi)ni MCCCCLXX q(ui)nto die vener(is) xx mens(is)septembr(is). Sit laus deo; Kantak, Spis książek z XV wieku (dokończenie), s. 271 nr 251. 
Większy problem sprawia czas powstania tłoków pieczętnych, którymi wyciśnięto wspomniane superekslibrisy. Wydarzeniem, które wpłynęło na zamówienie nowych tłoków, mogło być objęcie przez Mikołaja z Kościana urzędu oficjała w 1449 r. lub uzyskanie godności kanonika poznańskiego w 1454 r. Zdaniem Piotra Pokory forma pieczęci wskazuje jednak na późniejsze powstanie tłoków, najprawdopodobniej na początku $1470 \mathrm{r} .{ }^{17}$ Warto zauważyć, że doprecyzowanie datacji wykonania typariuszy byłoby możliwe w przypadku odnalezienia ich oryginalnych odcisków na listach bądź dokumentach Heskena.

Data powstania opraw wyznacza również czas wyciśnięcia superekslibrisów. Datacja wykonania znaków własnościowych przypadająca na 1475 r. niewątpliwie podnosi ich wartość pod względem chronologicznym. W literaturze za najstarsze uznaje się te związane ze środowiskiem krakowskim, które należą do: Mikołaja Byliny z Leszczyn profesora Akademii Krakowskiej datowany na lata 1466-1474 $4^{18}$, Andrzeja z Łabiszyna również profesora krakowskiej uczelni wyciśnięty pomiędzy 1470 a $1480 \mathrm{r} \cdot{ }^{19}$ oraz superekslibrisy właściwe pisarza i rajcy krakowskiego Johannesa Heydecke de Daminis datowane na lata1472-148020. W związku z powyższym superekslibrisy Mikołaja Heskena z Kościana można uznać za jedne $\mathrm{z}$ najstarszych w Polsce, a za najstarsze w Wielkopolsce. Wyjątkowość znaków własnościowych Heskena podkreślają także inne względy. Najnowsze badania wskazują, że w XV wieku formę niektórych superekslibrisów jedynie wzorowano na pieczęciach sygnetowych, natomiast przykład zastosowania tłoka pieczętnego do wycisku znaku własnościowego znany jest dopiero z drugiej połowy XVI wieku ${ }^{21}$. Tym samym oba rodzaje superekslibrisów Mikołaja Heskena są obecnie najstarszymi świadectwami użycia tłoków pieczętnych do tworzenia zna-

${ }^{17}$ Autor artykułu uzyskał niniejszą opinię od dr hab. Piotra Pokory podczas osobistej konsultacji w dniu 20 kwietnia 2017 r. w Poznaniu.

${ }^{18}$ A. Lewicka-Kamińska, Rzut oka na rozwój oprawy książkowej w Krakowie, „Roczniki Biblioteczne" 16 (1972) z. 1-2, s. 53, 62, il. 1; taż, Nieznane ekslibrisy polskie XVI wieku w Bibliotece Jagiellońskiej, Kraków 1974, s. 9; taż, Z dziejów dawnego bibliofilstwa w Krakowie, w: Silva Rerum, red. T. Ulewicz, Kraków 1981, s. 32; A. Wagner, Superekslibris Polski. Studium o kulturze bibliofilskiej i sztuce od średniowiecza do połowy XVII wieku, Toruń 2016, s. 117, tabl. I; tenże, Supralibros in Polen in der Zeit vom 15. Bis zur ersten Hälfte des 17. Jahrhunderts im Lichte neuerster Forschungen, „Einband Forschung”, (2014) H. 34, s. 55 il. 1.

${ }^{19}$ E. Chwalewik, Exlibriy polskie w XVI i XVII wieku, Wrocław 1955, s. 4-5; J.S. van Leeuwen, The Golden Age of Bookbindings in Cracow 1400-1600, Kraków 2011, s. 58-59; Lewicka-Kamińska, Z dziejów, s. 32-33; K. Piekarski, O superexlibrisie polskim, w: Katalog wystawy pięknej książki polskiej, Warszawa 1936, s. 30; A. Lewicka-Kamińska, Walenty z Pilzna, introligator krakowski XV wieku, „Roczniki Biblioteczne” 18 (1974) z. 1-2, s. 267-268; taż, Rzut oka, s. 53, 62 il. 2; Wagner, Superekslibris, s. 120, il. 32; tenże, Supralibros, s. 55; tenże, Włoskie wplywy w polskim introligatorstwie $X V$-XVI wieku, w: Tegumentologia polska dzisiaj, t. 1, red. A. Wagner, Toruń 2015, s. 84-85.

${ }^{20}$ van Leeuwen, The Golden, s. 62-63; Wagner, Superekslibris, s. 121-122, il. 33; W. Wisłocki, Incunabula typographica Bibliothecae Universitatis Jagellonicae Cracoviensis, Cracoviae 1900, s. 151, 15, 219, 232; Lewicka-Kamińska, Walenty, s. 267-268; taż, Rzut, s. 51.

${ }^{21}$ Wagner, Superekslibris, s. 417-418; Zob. M. Czyżak, Katalog rękopisów średniowiecznych Biblioteki Uniwersyteckiej w Toruniu, Torun 2016, s. 197-199, il. 157. 
ków własnościowych (superekslibrisów) na oprawach ksiąg. Warto zauważyć, że nie są jak dotąd znane żadne odciski pieczęci wykonane tymi tłokami, co w tej sytuacji czyni oprawy woluminów jedynymi dowodami na ich stosowanie. Niewykluczone, że szeroka kwerenda pozwoliłaby na ich odnalezienie w przyszłości. Natomiast w stosunku do tłoka ze św. Katarzyną należy się jeszcze jedna istotna uwaga. Postać świętej notowana jest na wielu pieczęciach europejskich ${ }^{22}$, lecz na superekslibrisach w Polsce nie jest mi znany żaden inny taki przykład.

Powyższe rozważania zdają się dość jednoznacznie wskazywać na znaczną wartość księgozbioru kanonika Mikołaja Heskena z Kościana dla historii książki w Polsce oraz sygnalizują potrzebę dalszych badań nad nim. Jednocześnie warto zwrócić uwagę na potencjał całego zbioru inkunabułów i starodruków w Archiwum Archidiecezjalnym w Poznaniu, który może kryć jeszcze niejedno cymelium.

\section{REFERENCES / BIBLIOGRAFIA}

\section{Źródła}

Archiwum Archidiecezjalne w Poznaniu (AAP)

sygn.: Inc. 149, Inc. 187, Inc. 278, Inc. 280, Inc. 313, Inc. 314, MS. 17.

\section{Opracowania}

Chwalewik Edward, Exlibriy polskie w XVI i XVII wieku, Wrocław 1955.

Czyżak Marta, Katalog rękopisów średniowiecznych Biblioteki Uniwersyteckiej w Toruniu, Torun 2016.

Dembiński Paweł, Poznańska kapituła katedralna schytku wieków średnich. Studium prozopograficzne 1428-1500, Poznań 2012.

Engel Bernhard, Die Mittelalterlichen siegel der fürsten, der geistlichkeit und de Polnischen adels in Thorner Rathsarchive, Danzig 1902.

Fjordholm O., Hohler E. B., Kjellberg H., Nyquist B., Norske sigiller fra middelalderen, Tredje bind: Geistlige segl fra Nidaros Bispedømme, Oslo 2012.

Gloria Deo. Rzemiosto sakralne, t. 2, red. M. Korżel-Kraśna, aut. oprac. T. Fercowicz i in., Wrocław 2010.

${ }^{22}$ B. Engel, Die Mittelalterlichen siegel der fürsten, der geistlichkeit und de Polnischen adels in Thorner Rathsarchive, Danzig 1902, s. 8-9, Taf. III nr 35; Gloria Deo. Rzemiosto sakralne, t. 2, red. M. Korżel-Kraśna, aut. oprac. T. Fercowicz i in., Wrocław 2010, s. 131-132 nr 143-144; O. Fjordholm, E.B. Hohler, H. Kjellberg, B. Nyquist, Norske sigiller fra middelalderen, Tredje bind: Geistlige segl fra Nidaros Bispedømme, Oslo 2012, nr 105, 133, 134; B.E. Hildebrand, Svenska sigiller från medeltiden, Första Bandet, Stockholm 1862-1867, s. 23 nr 282; A. Muzzi, B. Tomasello, A. Tori, Sigilli nel museo nazionale del Bargello. I ecclesiastici, Firenze 1988, s. 296-298 nr 780; H. Petersen, Danske geistlige sigiler fra middelalderen, Kjøbenhavn 1883, s. $6 \mathrm{nr}$ 66, s. $22 \mathrm{nr}$ 265, s. 23 nr 275, s. 24 nr 295, s. 31 nr 394, s. 35 nr 447, 451, 452, s. 36 nr 462, s. 45 nr 569, s. 77 nr 930, s. 82 nr 992; J. Sachsendahl, Siegel und Münzen de weltlichen und geistlichen Gebietiger über Liv-, Estund Curland bis zum Jahre 1561 nebst Siegeln einhemischer Geschlechter, Reval 1887, s. 129 nr 46. 
Hildebrand Bror Emil, Svenska sigiller från medeltiden utgifna, Första Bandet, Stockgolm 1862-1867.

Incunabula quae bibliothecis Poloniae asservantur, vol. 1, moderante A. Kawecka-Gryczowa, composuerunt M. Bohonos et E. Szandorowska, Wratislaviae-Varsaviae-Cracoviae 1970

Kantak Kamil, Spis książek z XV wieku Książnicy Seminarjum Duchownego w Poznaniu. Część pierwsza, „Rocznik Towarzystwa Przyjaciół Nauk Poznańskiego”, 45 (1918) s. 3-48.

Kantak Kamil, Spis ksiażek z XV wieku Ksiażnicy Seminarjum Duchownego w Poznaniu. Część pierwsza (dokończenie), „Rocznik Towarzystwa Przyjaciół Nauk Poznańskiego", 46 (1919) s. 243-311.

Krzyżaniakowa Jadwiga, Mikołaj z Kościana, w: Polski Słownik Biograficzny, t. 21, red. E. Roztworowski, Wrocław 1976, s. 116-117.

Leeuwen van Jan Storm, The Golden Age of Bookbindings in Cracow 1400-1600, Kraków 2011.

Lewicka-Kamińska Anna, Rzut oka na rozwój oprawy książkowej w Krakowie, „Roczniki Biblioteczne", 16 (1972) z. 1-2, s. 49-64.

Lewicka-Kamińska Anna, Nieznane ekslibrisy polskie XVI wieku w Bibliotece Jagiellońskiej, Kraków 1974.

Lewicka-Kamińska Anna, Walenty z Pilzna, introligator krakowski XV wieku, ,Roczniki Biblioteczne", 18 (1974) z. 1-2, s. 265-271.

Lewicka-Kamińska Anna, Z dziejów dawnego bibliofilstwa w Krakowie, w: Silva Rerum, red. T. Ulewicz, Kraków 1981, s. 29-40.

Lisiecki Arkadiusz, Katalog rękopisów biblioteki seminaryjnej w Poznaniu aż do wieku XV włącznie: dokończenie, Poznań 1905.

Muzzi Andrea, Tomasello Bruna, Tori Attilio, Sigilli nel museo nazionale del Bargello, I ecclesiastici, Firenze 1988.

Petersen Henry, Danske gejstlige Sigiller fra Middelalderen, Kjøbenhavn 1883.

Piechota Grażyna, Mikołaj z Kościana i jego księgozbiór, Folia Bibliologica, 48/49 (2006/2007, 2008) s. 25-39.

Piekarski Kazimierz, O superexlibrisie polskim, w: Katalog wystawy pięknej książki polskiej, Warszawa 1936.

Sachsendahl Johannes, Siegel und Münzen de weltlichen und geistlichen Gebietiger über Liv-, Est- und Curland bis zum Jahre 1561 nebst Siegeln einhemischer Geschlechter, Reval 1887.

Tadeusiewicz Hanna, Mikołaj z Kościana, w: Słownik pracowników książki polskiej. Suplement, I. Reichel, Warszawa 1986, s. 143.

Wagner Arkadiusz, Superekslibris Polski. Studium o kulturze bibliofilskiej I sztuce od średniowiecza do połowy XVII wieku, Toruń 2016.

Wagner Arkadiusz, Supralibros in Polen in der Zeit vom 15. Bis zur ersten Hälfte des 17. Jahrhunderts im Lichte neuerster Forschungen, „Einband Forschung”, (2014) H. 34, s. 54-62.

Wagner Arkadiusz, Wtoskie wptywy w polskim introligatorstwie XV-XVI wieku, w: Tegumentologia polska dzisiaj, t. 1, , red. A. Wagner, Toruń 2015, s. 81-106.

Wiesiołowski Jacek, Hesken Mikołaj z Kościana, w: Wielkopolski słownik biograficzny, A. Gąsiorowski, T. Topolski, Warszawa 1981, s. 252-253.

Wiesiołowski Jacek, Społeczeństwo a książka w późnośredniowiecznym mieście polskim Poznań i jego osiedla przedmiejskie w XV i na początku XVI wieku, „Studia Źródłoznawcze", 23 (1978) s. 65-81. 
Wisłocki Władysław, Incunabula typographica Bibliothecae Universitatis Jagellonicae Cracoviensis, Cracoviae 1900.

\title{
Netografia
}

Gesamtkatalog der Wiegendrucke (https://www.gesamtkatalogderwiegendrucke.de).

\section{LATE MEDIEVAL SUPER-LIBRARIES BY MIKOLAJ HESKEN OF KOŚCIAN. ITEMS FROM THE COLLECTION OF THE ARCHDIOCESAN ARCHIVES IN POZNAŃ}

\begin{abstract}
Remains of the late-medieval book collection of the Poznan canon Mikołaj Hesken of Kościan (d. 1485) are currently in the collection of the Archdiocesan Archives in Poznań. During his research, Fr. Kamil Kantak described his collection, paying attention to the „stamps" on the book covers. The author of the article, after carrying out a closer analysis, stated that the aforementioned „stamps” are Mikołaj Hesken's super-bookplates pressed with stamps. Further research has shown that it is a valuable material for the history of book proprietary marks in Poland. This is evidenced by, inter alia, chronology of super-bookplates, which makes them the oldest in Greater Poland.

Keywords: Mikołaj Hesken from Kościan; Archdiocesan Archives in Poznań, super-bookplate; Seal; Drogosław coat of arms; St. Katarzyna; Tegumentology; Bookbinding; Sphragistics
\end{abstract}

